\title{
The use of Confucian management thought in modern society
}

\author{
Lilei Ding \\ Hebei University \\ Hebei Finance University \\ Hebei, China
}

\author{
Yafei Hao \\ Hebei University \\ Hebei, China
}

\begin{abstract}
The Original Confucian "benevolence" as the core of thinking, emphasizes respect for people's status, the importance of the value of a man. After historical accumulation, the Confucian "people-oriented" has been deeply rooted in people's minds, has affected the modern people's life, world outlook and values. In the modern enterprise management practice, the management of the "people", to further deepen the shift from emphasis on "content" to "person", gradually to realize "people-oriented" the importance of the management mode. "Person" as the enterprise survival and development of the fundamental, meet people's needs, respect the wishes of people and to arouse the enthusiasm of people, make the enterprise obtain the driving force of development. Thus, Confucian "people-oriented" management thinking on the development of modern enterprise managers management thought, and realize the sustainable development of the modern enterprise to vital significance.
\end{abstract}

Keywords- the Confucian management thought; Respect; "People-oriented" Concept

\section{INTRODUCTION}

Confucius said: "Pan Focus love, and benevolent." Mencius: "The world of nature, man is foremost" "people, boat followed, the king of light." Xunzi:. "Monarch who is also the boat, the water is also commoners water boat, water will overturn it." Appears in the pre-Qin Confucianism in the simple thought of the people are "benevolence" as the core, to promote respect for person's status, importance of human values. After the accumulation of history, Confucian "People thought" has been deeply rooted in the hearts of modern, affecting modern life, world outlook and values. In the modern business management practices, managers of "person" to further deepen the understanding undergone a transition from the emphasis on "material" to the importance of "people", the gradual recognition of the "people-oriented" management model. The business people as the fundamental business survival and development to meet the people's needs, concerns into development, respect for human will to take all means to mobilize people's enthusiasm. This intake Confucian "People thought," the man of the modern enterprise management, both on the local cultural heritage and development, but also help achieve an important guarantee for the modern enterprise for sustainable development.

\section{A Benevolent Virtue: Attention by Managers}

\section{A. Education is the Main Channel of Human Development}

Focus on human development Confucianism realize that education is the main channel of human development. As we all know, the founder of Confucianism itself is a great educator of Confucianism. He raised the "No Child Left Behind" education thought, and made a "learning While Learning," "Reviewing the Old", "Making introspection three times daily," and so on teaching and learning discuss methods. Confucius'I studyed for myselfs before and for human beings now. "Say study is not only to improve their own morality and spiritual realm, is to turn knowledge into a service society capacity and ability to settle down in the community.

People management is a kind of promotion of human development as the fundamental purpose of management concern is the development of managers, the importance of employee education and training is one of its important features. Studies show that people who work every three to five years after its original knowledge learned eighty percent has been used in the same job, if not a new study, then he will lose the next creative work. Only through new learning and training, the addition of new knowledge, new skills and increase his knowledge and ability to meet the development needs of the work. Therefore, the modern enterprise management is very focused on providing learning and training managers the opportunity to be at the same time improving the overall level of employees, to enable enterprises to master the forefront of industry trends and technology, with a source of innovation, maintain business competitiveness in the market

\section{B. Recognize and Respect the Needs of Material Desires and Interests of the People}

Confucianism "People thought," is to recognize and respect the needs of material desires and interests of the people, "is seeking people of the day from God.." Confucius said: "The riches and honour, is one of the objectives, not its road, do not place it; poor and cheap, is also the evil person, not its road, do not have." Noted aspire to wealth, poverty is that people do not like common psychological, if not unscrupulous, to "gentleman's love of money, in a proper way," "And that, in governing the country." sufficient food and soldiers will make people believe in us. "that is prepared 
adequate food and the army, the people will trust the rulers. This reminds the ruler to the right to face the public demand for food and materials, to address them and can not be avoided. The so-called "warehouse enjoy real conceivable manners, fed with knowledge of honor", concerns and meet the material needs of the people, is to mobilize the enthusiasm of the people, to achieve effective management of the premise.

Modern business people in this administration that attaches great importance to respect and meet the needs of employees, This aspect is reflected in the gradual establishment of a modern enterprise system in a fair and reasonable incentive, through targeted incentives, assessment and incentive, motivation and even emotional incentive opportunities and other ways to mobilize the enthusiasm of the staff, to the staff staged encouragement. On the other hand is also reflected in the modern enterprise gradually improving labor welfare system. Mencius said, "Possessions perseverance," the modern enterprise to meet employees 'needs in terms of safety awareness, provide a good working environment and working conditions for employees, to provide "insurance policy" for the employees' constant production. " On this basis, the staff is trust and dependence on business, this is the employee's sense of belonging, "perseverance", prompting employees are more willing to pay for long-term efforts for the enterprise.

\section{ESTABLISH EXEMPLARY ROLE OF MANAGERS}

\section{A. Managers Need to Improve Their Self-cultivation}

The Confucian classic" Book of Rites University " expresses its main idea"The discussion considers those who want to demonstrate their virtue in the world, first learn to control a country; wants to govern a country, we must first manage an entire family; want to manage a family, we must first improve their training. Only the manager's own morality reaches a certain level, have the ability to govern a country. "As Confucianism researcher Yang Chaoming said:. "Confucius as the representative of the Confucian doctrine is the doctrine of social management, by its very nature is cultivating man management theory" This theory is actually made from the perspective of management science requirements for managers, namely: Managers need to improve their self-cultivation.

\section{B. "People-oriented" Concept of Modern Management}

In fact, at any age, the quality of managers have decided on a business, rise and fall of groups and even national survival. Worry-free future human resource services had done "the most popular employer" vote, and to investigate thirteen thousand service personnel to vote. Survey shows that employees generally have higher expectations of managers, they have higher expectations of professionalism and strong charisma influential. More than $92 \%$ of the participants said the impact of the manager's attitude and mental state and motivation of their maximum. "Knows nothing, doubts nothing," people on the side of the people have a natural tendency to imitate, so Mencius said, "Nobody but the benevolent people should be in the high position"So people-oriented management of modern enterprises, requiring managers to manage others, we must also manage their own, establish an exemplary role. First, to improve their charisma. People management requires managers to itself become a moral character, mentality sun, positive, diligence and self-discipline, impartial person, and constantly improve their own influence. The second is to become a positive role model. In a rapidly changing knowledge era, people management requires managers to constantly update their own ideas for new things to learn more than the staff, learn faster, with outstanding scientific and forward-looking business management and decision-making. Three is to become a model implementation. Modern enterprise management often faced managers do not perform, lazy execution status of employees, resulting in the entire enterprise shortfalls execution problems. The solution to this contradiction is that managers establish an exemplary role in the implementation of, compliance with corporate rules and regulations, curried, subject to the overall situation, the first demonstration, to promote enterprise practice new work style.

\section{A HARMONIOUS RELATIONSHIP IS THE KEY IN THE} RELATIONSHIP BETWEEN ADMINISTRATORS AND MANAGERS

Confucian doctrine of "harmony" as the highest value. Confucianism "harmony" management philosophy is actually starting from the people, focusing on the relationship between coordination between people, resolve conflicts between people, the formation of a higher unity. The pursuit of the pursuit of modern enterprise people management is consistent. Modern enterprise focusing on the harmonious relationship between the administrators and managers of that good superior-subordinate relationship is the key to development. The "harmony" state can not only resolve the conflicts and contradictions between managers and managed more easily between member companies produce fit sincere emotion and soul, to form good communication in an organization, the same ideas, the goal of reunification, and promote a business thrive. To form the "harmony" of the situation, the modern enterprise focusing on the following aspects of the relationship between process management and managers in People Management.

\section{A. the thought of Respect}

"People thought of" respect for the most basic feature is "human." The core of the Confucian doctrine of "benevolence" is also asked to use respect and compassion look at people. Mencius that "people are the boat followed, the king of light." Considered among the rulers, the development of the boat and the people, the people are the most important. And if respect subordinates, but also on the status of rulers play a very critical role. The management of modern enterprises who draw their spirit, in the management of corporate affairs of great importance to respect their opinions. Enterprises and gradually establish a workers' congress system, the staff to grasp the dynamics of enterprises, and to participate in their views, participate in the management and supervision of enterprises. Especially related to employee benefit decisions and major decisions are focused by a certain percentage of employees agree. In such 
a people-oriented management, the willingness of employees have been fully respected, relationship managers and managed the transition from the leadership of the relationship between leadership and the kind of division of labor relations for equality, to create a harmonious working atmosphere autonomy within the enterprise.

\section{B. The thought of Benevolence}

Confucianism can use a word to summarize. So what exactly is "benevolence"? It is recorded that one day Fan Chi asked Confucius what is "benevolence", Confucius replied, "Love." In other words, Confucius put "love" as a starting point and benevolent heart. The concept of "benevolent" thinking this modern management thinking, requires managers in management practice should be caring attitude towards managers, benefit the people, so that "Do as you would be done by." And standing on the perspective of managers are thinking, caring for family members with the mentality to care for employees. Modern enterprise introduction of this simple humanism care, advocates sincerely to love people in management practice, inclusive shortcomings of staff, sincerely recommendations for employees, employees' glittering and promptly found encouragement, understanding attitude with Care staff done in a timely manner to provide them with emotional care and spiritual encouragement.

\section{Keep the Ritual}

The pursuit of a harmonious relationship between administrators and managers, in addition requires managers to be fully respected and care managers, but also requires managers in a "ritual" standard to restrict and regulate itself and managers get along. Confucius proposed that everyone knows their position and norms, norms between managers and the managed and orderly. Xunzi reminded managers, in promoting "people-oriented", to promote the full development of the staff while not ignoring the constraints of enterprises and orderliness. Develop a scientific and effective management system, so that the work of rule-based, management subject and object while observing etiquette is to establish a harmonious relationship between good internal security.

\section{CONCLUSION}

To realize humanistic management in modern enterprises, the management of the harmonious relationship is the key, "respect for people" in the modern enterprise management the simple humanistic care, to advocate sincere people who love each other in the management practice; "Benevolence" advocated in the management practice, care and understanding of the staff attitude, timely and provide them with emotional care and spiritual encouragement. "The ritual" the thought requires managers in a "the ritual" the standards of constraints, and self-regulation and management, formulate scientific and effective management system, to establish a harmonious management relationship. "Harmony", not only can solve the conflict between managers and the contradiction, more easily and member enterprise production in line with the sincere emotion and soul, to form a good communication, the same concept, unified management by objectives, to promote the business thrive.

\section{ACKNOWLEDGEMENTS}

Ding liLei, Hebei University $\mathrm{PhD}$, Chinese philosophy and cultural studies, Hebei Finance University lecturer, research direction.; Hao Yafei, associate research direction for China Hebei University Management Thought philosophy.

\section{References}

[1] Shen Ying,Shenchun Ping. Analysis of Chinese ancient management thought-Based on the perspective of modern theory [J] Technology horizon.2014(9)

[2] Duanling XUE. Application of Confucius thoughts in management[J]Oriental Enetental Enterprise.2014(1)

[3] Puxiao Mei. The Confucian "benevolence righteousness" thought and the new management mode[J] The decision to explore (The second half).2014(9)

[4] JuneM.L.Poon. Effects of benevolence, integrity, and ability on trustin-supervisor[J]Employee Relations, 2013, Vol.35 (4), pp.396-407 